Bangladesh J. Sci. Res. 27(2): 109-120, 2014 (December)

\title{
EVALUATION OF HYDROGEOLOGICAL CONDITIONS THROUGH VERTICAL ELECTRICAL SOUNDING SURVEY AT MANKIGANJ POURASHAVA, MANIKGANJ, CENTRAL PART OF BANGLADESH
}

\author{
A. S. M. Woobaidullah", M. Moklesur Rahman ${ }^{1}$, M. Zohir Uddin ${ }^{2}$ \\ Department of Geology, University of Dhaka, Dhaka 1000, Bangladesh
}

\begin{abstract}
The Pourashava area of Manikganj, located in the central part of Bangladesh is treated as arsenic hotspot in the country as the outcome of various studies concludes that almost $80 \%$ of the domestic tube wells at this area exceed arsenic level of Bangladesh standard $(50 \mu \mathrm{g} / \mathrm{l})$ for drinking water. To enhance the potable water supply in the area, 15 geoelectric soundings survey using Schlumberger configuration with spreading $\mathrm{AB} / 2=300$ meters has been executed to decipher the subsurface lithology distribution and aquifers at different depths, to determine the lateral and vertical extent of aquifer at the area. Correlation of the analyzed VES results with primary and secondary borelogs, the subsurface sequence of the area is broadly divided into two geoelectric units. Firstly, the near surface geoelectric unit of resistivity less than $20.0 \Omega$-m represents the top soil composed of silty clay to clay. The thickness of this layer varies from 1 meter to 5 meters. The second geoelectric unit represents the sand layer and is characterized by a resistivity range of 21.0 to $190.0 \Omega-\mathrm{m}$. This unit encompasses the very fine sand with variable thickness of 2 to $248 \mathrm{~m}$ while resistivity is from 21.0 to $30.0 \Omega-\mathrm{m}$, very fine to fine sand having thickness from $174-280 \mathrm{~m}$ and geoelectric value ranges from 31.0 to $40.0 \Omega-\mathrm{m}$, fine sand with resistivity from 44.0 to $50.0 \Omega-\mathrm{m}$, fine to medium sand having resistivity from 51.0 to $70.0 \Omega-\mathrm{m}$, medium sand and medium to coarse sand with resistivity value 75.0 to $110.0 \Omega-\mathrm{m}$, and 140.0 to $190.0 \Omega-\mathrm{m}$, respectively. The ultimate thickness of this unit could not be determined due to limited spread of survey but at least continues to a depth of $300 \mathrm{~m}$. In the context of groundwater storage, the second geoelectric unit acts as the regional aquifer and is used for groundwater development in the Pourashava area for water supply.
\end{abstract}

Key words: Groundwater, geoelectric, VES, aquifer, Manikganj

\section{Introduction}

Bangladesh is mothered by rivers and availability of water is not a big problem but the question remains with quality of water. In recent years the presence of elevated concentration of various organic and inorganic pollutants from natural and anthropogenic

\footnotetext{
"Corresponding author: <woobaid.du@gmail.com>. ${ }^{1}$ Department of Petroleum and Mining Engineering, Jessore University of Science and Technology, Jessore. ${ }^{2}$ Geological Survey of Bangladesh.
} 
sources has limited the availability of safe water. Among drinking water pollutants, arsenic (As) is regarded as the most formidable contaminant on a global scale (ATSDR 2007).

The Bengal Delta formed by the sedimentation of the rivers Ganges-Brahmaputraand Meghna along with their numerous tributaries and distributaries is the world's largest fluvio-deltaic basin. Groundwater in Holocene sediments is reported as highly contaminated with arsenic rather than the sediments deposited in Tertiary Age. Manikganj Pourashava in Manikganj district is covered by a sequence of fluvial deposits of Quaternary age. Taking spatial distribution (BGS and DPHE 2001) and severity of arsenic contaminant in groundwater into account, shallow aquifer in and around Manikganj Sadar is considered a remarkable hotspot in Bangladesh.

Installation of tubewells into deep aquifer could be used to tap potable water as an alternative potential source to meet the growing demand for sound lives. It is now urgent to conduct an extensive survey to assess the hydrogeological condition of the area. With the advent of technology, Geo-electrical Resistivity Survey especially Vertical Electrical Soundings (VES) for delineating aquifer geometry as well as appraising groundwater resources has proved to be very effective and reliable (Bugg and Lloyed 1976 Serres, 1969 Woobaidullah et al. 1996). Moreover, in Bengal Basin this method obtains about 90\% reliability of natural distribution of subsurface lithology (Rahman et al. 2013). Therefore, an extensive Vertical Electrical Resistivity Soundings Survey using Schlumberger configuration with spreading $\mathrm{AB} / 2=300$ meters has been carried out to evaluate the hydrogeological condition for developing groundwater resources through deep tube wells in the Pourashava area of Manikganj to enhance the water supply in the area. Specific objectives include subsurface distribution of lithology, demarcation of the aquifer and its vertical position and lateral extent.

\section{The study area}

The study area Manikganj Pourashava is about $60 \mathrm{~km}$ west of Dhaka city and is well connected to the capital city by Dhaka Aricha high way, covers an area of about 20.59 sq $\mathrm{km}$ with a population of around 54,000. The study area encompasses 9 Wards and 49 Mahallas. The situation of arsenic contamination in Manikganj Pourashava and its surroundings is high as revealed by BRAC and other organizations in the previous years. The area lacks sufficient information on lithology. The nature and extent of arsenic contamination is still unknown. Moreover, the information on vertical and the lateral extent of the aquifer is inadequate. Few former hydrogeological investigations through exploratory drillings provided scattered and limited information about the aquifer and water quality of the study area (Fig. 1). 


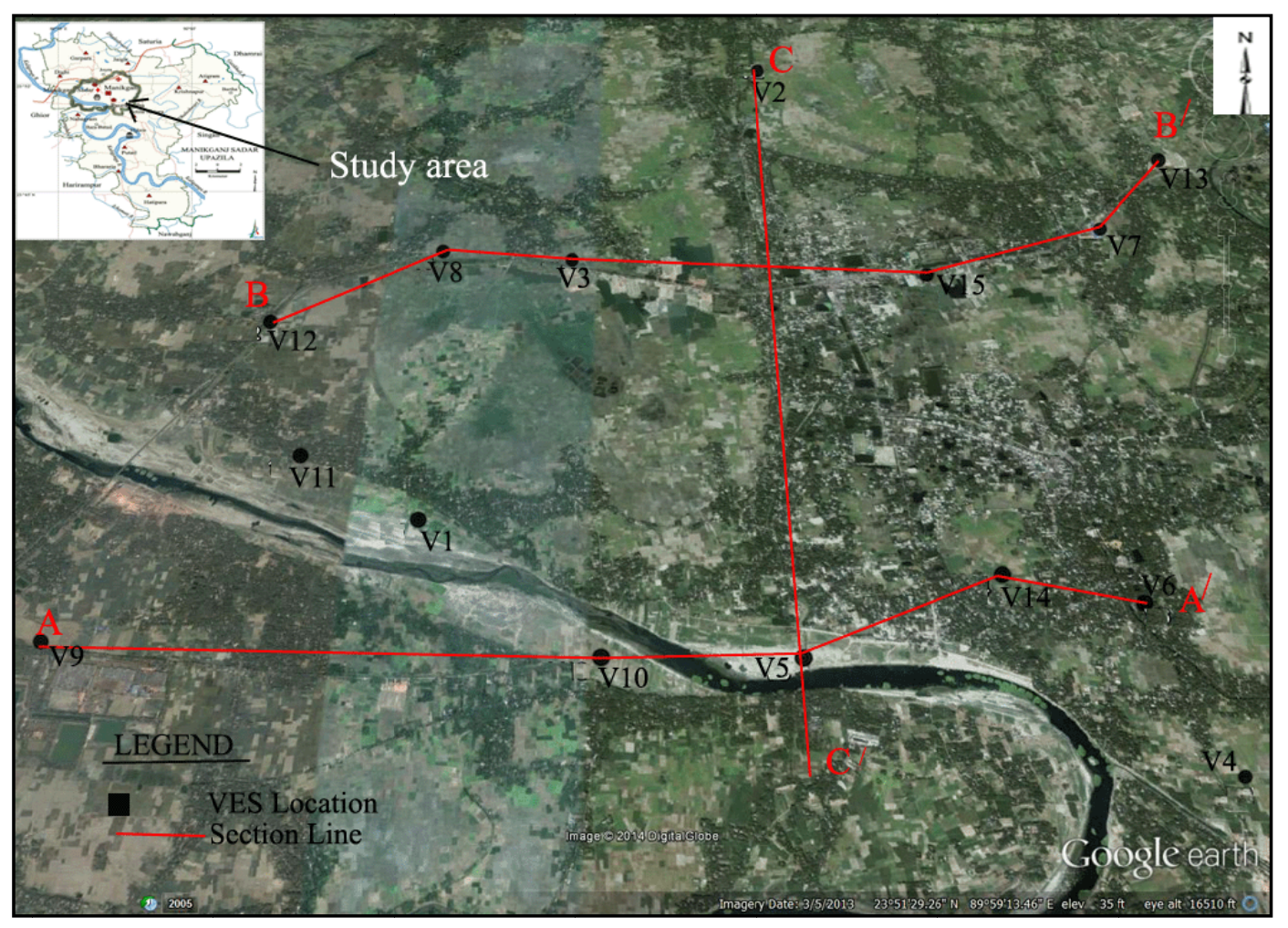

Fig. 1. Location map of the study area showing VES positions and Section lines.

\section{Geology and hydrogeology of the area}

Manikganj and its surrounding areas are in the eastern floodplain of Jamuna River. The river flows along north-south trending neotectonic depression, known as Jamuna depression in between Madhupur High in the east and Barind Tract in the west. The western margin of Madhupur High is bounded by series of six-en-echelon faults ranging from 10 to $20 \mathrm{~km}$ long with minimum throw of 5 to $15 \mathrm{~m}$. The major basement fault that demarcates Madhupur High from Jamuna depression is known as Madhupur fault. Manikganj being situated in the southern periphery of Madhupur High and on the junction of Madhupur High and Jamuna depression is likely to be affected by some faults. One such fault almost north-south trending is passing along Kaliganga River of Manikganj.

The Quaternary deposits of the study area, as revealed by the available lithologs of BWDB boreholes (up to $184 \mathrm{~m}$ ) can be divided into three broad units. The lower unit is a fine to medium grained sand, which is grey at the bottom and light yellow to grey at the top. The unit starts at depths ranging from 100-110 $\mathrm{m}$ and extends up to the total drilled 
unit fines upward and dominantly composed of fine to medium grained sand with coarse sand and occasional gravel at the bottom. Alternating layers of clay and fine sand of variable thickness separates these two units. The upper $2-10 \mathrm{~m}$ is alluvial deposits of silty clay with very fine sand.

The sand sequence above the discontinuous thin clay/silty clay layer comprises, as referred, the upper aquifer. The sequence of fine to medium sand with occasional coarse sand and gravel that occurs below this clay layer up to the drilled depth of $185 \mathrm{~m}$ is termed as lower or deep aquifer. As the clay/silty clay layer is thin and discontinuous the upper and lower aquifers may be in hydraulic connection.

As per UNDP (1982) report, hydrogeologically the study area is situated in zone ' $\mathrm{B}$ ' which consists primarily of old flood plain deposits of the Jamuna River.

\section{Materials and Methods}

Fifteen vertical electrical soundings have been carried out adopting Schlumberger configuration with spreadings $600 \mathrm{~m}(\mathrm{AB} / 2=300 \mathrm{~m})$ in the area. In this method, artificially generated electric currents are introduced into the ground through a pair of current electrodes remaining outside and the resulting potential differences are measured at the surface through another inner pair of potential electrodes. The array configured by four electrodes is positioned symmetrically along a straight line driven into the ground to make a good contact with the earth. The current electrode spacing is progressively increased to increase the depth range of the measurements, while the potential electrode spacing, in general, is left unchanged. When the ratio of the distance between the current electrodes to the potential electrodes becomes too large, the potential electrodes spacing must also be expanded otherwise the potential difference becomes too small to be measured with sufficient accuracy. A McOHM (Model-2115), OYO corporation, Tokyo, Japan, Digital Electrical Prospecting System was used to collect the field data. The instrument is incorporated with stacking processing function to improve signal/noise ratio as desired. It is a compact device housing the transmitter (current supply unit) and the receiver (potential measuring unit) in a case. During sounding, it performs automatic recording of both voltage and current, stacks the results, computes the resistance in real time and digitally displays it. Interpretation of the collected VES data, in the first step, is done manually following the partial curve matching technique. In next step, the manually interpreted results have been used as the input model for software based interpretation of the VES data. The software used for the purpose is 'RESISTIV'. Available borelogs were gathered from local stakeholders (BWDB). Correlation has been made of VES results with available borelogs and fixed the ranges of resistivity value for different subsurface lithology. Lithology distribution maps were prepared by using the Rockware - 2004 and Surfer 8.3 software. In addition, Arc GIS 9.2 was also used for mapping the location of the study area and the Sounding points. 


\section{Results and Discussion}

Resistivity, the most variable physical parameter controlled by porosity, nature of pore fluid, composition of rock materials, compaction, age of the rock and nature of the overburden sediments, is very useful to identify aquifers and to distinguish fresh and saline water interface (Serres 1969, Woobaidullah et al. 1996 1998). The subsurface geology based on borelogs as well as the empirical knowledge has been used as a rationale to interpret the VES results. Analyzed resistivity parameter (Table 1) shows a wide range of value suggesting the complex nature of the subsurface in lateral as well as vertical directions. The subsurface geology up to explored depth is broadly categorized into top soil, clay, very fine sand, very fine to fine sand, fine sand, fine to medium sand, medium sand and medium to coarse sand. The top soil with a thickness of 1 meter to 5 meter in the area is characterized by a variation of resistivity values $(1.0 \Omega-\mathrm{m}$ to12.0 $\Omega$ $\mathrm{m})$. Variation of resistivity parameter for top soil is the reflection of dry and wet nature of the surface materials. Higher resistivity corresponds to dry and compacted silty soil while clayey moistured soil shows lower resistivity. The delineated subsurface lithology below the top soil is randomly distributed in lateral and vertical context of the study area. Very fine to fine sand and fine sand units are observed in most of the study area immediate below the top soil. Medium sand unit is found to occur in between very fine to fine sand and fine sand units but at few places it occurs as first unit beneath the top soil. Clay/silty clay unit is identified at two VES locatios (VES 11 and 14) at 3 to 5m depth levels. Depth level, thickness and corresponding resistivity values acquired for all of the deciphered units vary throughout the study area. Very fine sand unit that occurs at different depth levels shows resistivity ranging from $21.0 \Omega-\mathrm{m}$ to $30.0 \Omega-\mathrm{m}$ with a thickness variation of 2 to 248 meter.

From analysis of VES results it is perceptible that the lower resistivity value is characteristic for silty clay to clay unit. It has been found that clay unit present at only two locations (VES 11 and 14) with thickness of $8 \mathrm{~m}$ and $5 \mathrm{~m}$ while the corresponding resistivity values are $12.0 \Omega-\mathrm{m}$ and $15.0 \Omega-\mathrm{m}$, respectively. The thickness and corresponding resistivity of very fine to fine Sand unit are different but varies within a reasonable range. The characteristic resistivity value of the unit ranges from $31.0 \Omega-\mathrm{m}$ to $40.0 \Omega-\mathrm{m}$ and the thickness variation is within the scale of 174 meter to 280 meter (except VES 7). The fine sand, more localized unit exists in very shallow depth at north eastern corner of the area while appears as lowest unit in middle south-western part at VES I location. At shallow depth, it has been found as very thin layer at locations VES 13 and VES 15 with the value of 1 and $4 \mathrm{~m}$, respectively. Reasonable thickness of this unit has been demarcated at VES 7 and VES 1 as 94 and $227 \mathrm{~m}$, respectively. 
Table 1. Analyzed VES results after correlation with borelogs.

\begin{tabular}{|c|c|c|c|c|c|}
\hline \multicolumn{3}{|c|}{ VES No-1 } & \multicolumn{3}{|c|}{ VES No-2 } \\
\hline $\begin{array}{l}\text { Thickness } \\
\text { (m) }\end{array}$ & $\begin{array}{l}\text { Resistivity } \\
\text { (ohm-m) }\end{array}$ & Geoelectric unit & $\begin{array}{l}\text { Thickness } \\
\text { (m) }\end{array}$ & $\begin{array}{l}\text { Resistivity } \\
\text { (ohm-m) }\end{array}$ & Geoelectric unit \\
\hline 1.5 & 1.5 & Top soil (silty clay/clay) & 1 & 12 & $\begin{array}{l}\text { Top soil (silty } \\
\text { clay/clay) }\end{array}$ \\
\hline 12 & 75 & Medium sand & 4.5 & 86 & Medium sand \\
\hline 60 & 52 & Fine to medium sand & 18 & 58.5 & $\begin{array}{l}\text { Fine to medium } \\
\text { sand }\end{array}$ \\
\hline \multirow[t]{2}{*}{227} & 45 & Fine sand & 97 & 54 & $\begin{array}{l}\text { Fine to medium } \\
\text { sand }\end{array}$ \\
\hline & & & 180 & 30 & $\begin{array}{l}\text { Very fine to fine } \\
\text { sand }\end{array}$ \\
\hline \multicolumn{3}{|c|}{ VES No-3 } & \multicolumn{3}{|c|}{ VES No-4 } \\
\hline $\begin{array}{l}\text { Thickness } \\
\text { (m) }\end{array}$ & $\begin{array}{l}\text { Resistivity } \\
\text { (ohm-m) }\end{array}$ & Geoelectric unit & $\begin{array}{c}\text { Thickness } \\
\text { (m) }\end{array}$ & $\begin{array}{l}\text { Resistivity } \\
\text { (ohm-m) }\end{array}$ & Geoelectric unit \\
\hline 1.8 & 9.5 & Top soil (silty clay/clay) & 1 & 1 & $\begin{array}{l}\text { Top soil (silty } \\
\text { clay/clay) }\end{array}$ \\
\hline 77 & 51 & Fine to medium sand & 2 & 35 & $\begin{array}{l}\text { Very fine to fine } \\
\text { sand }\end{array}$ \\
\hline \multirow[t]{2}{*}{223} & 32.5 & Very fine to fine sand & 45 & 80 & Medium sand \\
\hline & & & 252 & 35 & $\begin{array}{l}\text { Very fine to fine } \\
\text { sand }\end{array}$ \\
\hline \multicolumn{3}{|c|}{ VES No-5 } & \multicolumn{3}{|c|}{ VES No-6 } \\
\hline $\begin{array}{l}\text { Thickness } \\
\text { (m) }\end{array}$ & $\begin{array}{l}\text { Resistivity } \\
\text { (ohm-m) }\end{array}$ & Geoelectric unit & $\begin{array}{l}\text { Thickness } \\
\text { (m) }\end{array}$ & $\begin{array}{l}\text { Resistivity } \\
\text { (ohm-m) }\end{array}$ & Geoelectric unit \\
\hline 1 & 3.5 & Top soil (silty clay/clay) & 1 & 3.8 & $\begin{array}{l}\text { Top soil (silty } \\
\text { clay/clay) }\end{array}$ \\
\hline 2 & 24 & Very fine sand & 3 & 27 & Very fine sand \\
\hline 70 & 60 & Fine to medium sand & 61 & 60 & $\begin{array}{l}\text { Fine to medium } \\
\text { sand }\end{array}$ \\
\hline 228 & 22 & Very fine sand & 235 & 28 & Very fine sand \\
\hline \multicolumn{3}{|c|}{ VES No-7 } & \multicolumn{3}{|c|}{ VES No-8 } \\
\hline $\begin{array}{l}\text { Thickness } \\
\text { (m) }\end{array}$ & $\begin{array}{l}\text { Resistivity } \\
\text { (ohm-m) }\end{array}$ & Geoelectric unit & $\begin{array}{c}\text { Thickness } \\
\text { (m) }\end{array}$ & $\begin{array}{l}\text { Resistivity } \\
\text { (ohm-m) }\end{array}$ & Geoelectric unit \\
\hline 1.5 & 4.7 & Top soil (silty clay/clay) & 2 & 2 & \multirow{5}{*}{$\begin{array}{l}\text { Top soil (silty } \\
\text { clay/clay) } \\
\text { Very fine sand } \\
\text { Medium to } \\
\text { coarse sand } \\
\text { Very fine to fine } \\
\text { sand }\end{array}$} \\
\hline 1.5 & 33 & Very fine to fine sand & 3 & 30 & \\
\hline 94 & 48 & Fine sand & 15 & 180 & \\
\hline 54 & 60 & Fine to medium sand & 280 & 35 & \\
\hline 150 & 25 & Very fine sand & & & \\
\hline
\end{tabular}


(Contd.)

\begin{tabular}{|c|c|c|c|c|c|}
\hline \multicolumn{3}{|c|}{ VES No-9 } & \multicolumn{3}{|c|}{ VES No-10 } \\
\hline $\begin{array}{c}\text { Thickness } \\
(\mathrm{m})\end{array}$ & $\begin{array}{l}\text { Resistivity } \\
\text { (ohm-m) }\end{array}$ & Geoelectric unit & $\begin{array}{c}\text { Thickness } \\
\text { (m) }\end{array}$ & $\begin{array}{l}\text { Resistivity } \\
\text { (ohm-m) }\end{array}$ & Geoelectric unit \\
\hline 5 & 12 & Top Soil (silty clay/clay) & 1.5 & 4.7 & $\begin{array}{l}\text { Top soil (silty } \\
\text { clay/clay) }\end{array}$ \\
\hline 8 & 28.5 & Very fine sand & 1.5 & 29 & Very fine sand \\
\hline 100 & 60 & Fine to medium sand & 10 & 23.5 & Very fine sand \\
\hline \multirow[t]{3}{*}{187} & \multirow[t]{3}{*}{21} & \multirow[t]{3}{*}{ Very fine sand } & 4 & 140 & $\begin{array}{l}\text { Medium to } \\
\text { Coarse sand }\end{array}$ \\
\hline & & & 20 & 25 & Very fine sand \\
\hline & & & 247 & 150 & $\begin{array}{l}\text { Medium to } \\
\text { Coarse sand }\end{array}$ \\
\hline \multicolumn{3}{|c|}{ VES No-11 } & \multicolumn{3}{|c|}{ VES No-12 } \\
\hline $\begin{array}{l}\text { Thickness } \\
\text { (m) }\end{array}$ & $\begin{array}{l}\text { Resistivity } \\
\text { (ohm-m) }\end{array}$ & Geoelectric unit & $\begin{array}{l}\text { Thickness } \\
\text { (m) }\end{array}$ & $\begin{array}{l}\text { Resistivity } \\
\text { (ohm-m) }\end{array}$ & Geoelectric unit \\
\hline 1 & 3 & Top soil (silty clay/clay) & 1 & 3 & $\begin{array}{l}\text { Top soil (silty } \\
\text { clay/clay) }\end{array}$ \\
\hline 2 & 25 & Very fine sand & 7 & 25 & Very fine sand \\
\hline 2 & 80 & Medium sand & 15 & 21 & Very fine sand \\
\hline 8 & 12 & Silty clay to clay & 29 & 100 & Medium sand \\
\hline 59 & 70 & Fine to medium sand & 248 & 29 & Very fine sand \\
\hline 230 & 31 & Very fine to fine sand & & & \\
\hline \multicolumn{3}{|c|}{ VES No-13 } & \multicolumn{3}{|c|}{ VES No-14 } \\
\hline $\begin{array}{c}\text { Thickness } \\
(\mathrm{m})\end{array}$ & $\begin{array}{l}\text { Resistivity } \\
\text { (ohm-m) }\end{array}$ & Geoelectric unit & $\begin{array}{c}\text { Thickness } \\
(\mathrm{m})\end{array}$ & $\begin{array}{l}\text { Resistivity } \\
\text { (ohm-m) }\end{array}$ & Geoelectric Unit \\
\hline 1 & 4 & Top soil (silty clay/clay) & 2 & 3.5 & $\begin{array}{l}\text { Top soil (silty } \\
\text { clay/clay) }\end{array}$ \\
\hline 1 & 44 & Fine sand & 1 & 25 & Very fine sand \\
\hline 8 & 190 & Medium to coarse sand & 5 & 15 & $\begin{array}{l}\text { Silty clay to } \\
\text { Clay }\end{array}$ \\
\hline 25 & 25 & Very fine sand & 40 & 110 & Medium sand \\
\hline 70 & 90 & Medium sand & 80 & 22 & Very fine sand \\
\hline 196 & 30 & Very fine sand & 174 & 32 & $\begin{array}{l}\text { Very fine to fine } \\
\text { sand }\end{array}$ \\
\hline \multicolumn{6}{|c|}{ VES No-15 } \\
\hline $\begin{array}{c}\text { Thickness } \\
\text { (m) }\end{array}$ & $\begin{array}{l}\text { Resistivity } \\
\text { (ohm-m) }\end{array}$ & Geoelectric unit & & & \\
\hline 2 & 10 & Top soil (silty clay/clay) & & & \\
\hline 4 & 50 & Fine sand & & & \\
\hline 5 & 21 & Very fine sand & & & \\
\hline 50 & 100 & Medium sand & & & \\
\hline 240 & 25 & Very fine sand & & & \\
\hline
\end{tabular}


The distinguished resistivity value of the unit varies from 44.0 to $50.0 \Omega-\mathrm{m}$. The fine to medium sand unit with insignificant thickness $(2 \mathrm{~m})$ to remarkable thickness $(115 \mathrm{~m})$ distributed all over the area discontinuously. The characteristic resistivity value of the unit varies from 51.0 to $70.0 \Omega-\mathrm{m}$, while the encountered depth varies at different locations. The medium Sand unit delineated at different depths at different locations shows wide variation in thickness as well as resistivity value. It encompassed the resistivity in the range of 75.0 to $110.0 \Omega-\mathrm{m}$. The thickness of this layer is reasonable and in the range of 2 to 70 meters. It has been suspected that the fine to medium Sand and medium sand units play vital role to serve as a potable potential groundwater aquifer in the study area. These units are also confirmed by the borehole data available in the study area. These units encountered at different depths with different thicknesses, and somewhere they occur at very close to the surface even just after the top soil. On the other hand, they appear as the bottom most units in few places. The medium to coarse sand unit attained the highest resistivity range that varies from 140.0 to $190.0 \Omega-\mathrm{m}$ and obtained thickness ranges from 4 to $15 \mathrm{~m}$ except in VES 10 where it is about 247 meter.

Two-dimensional and 3-dimensional subsurface models are prepared from VES results to represent the vertical distribution of subsurface lithology along with lateral extent. Three 2-dimensional cross-sections stretching approximately E-W and N-S directions (Fig. 1) describe the existence of six distinct lithologic units excluding top soil and clay units as they have very little thickness.

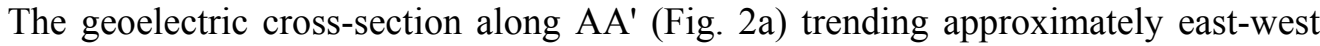
direction along the southern part of the area covers the distribution of all available units in the study area. In spite of having limited thickness, the top soil is more or less continuous along the section. It is deduced from the section that all the sandy units along the section have reasonable thickness but the distribution regarding the vertical and lateral continuity do not coincide in different places.

The very fine sand unit, the dominant in proportion to other units is distributed in scattered pattern (Fig. 2a) while in the eastern and the western margins this unit occurs at greater depths. The middle portion of the section shows the dominance of medium to coarse sand unit of thickness more than $250 \mathrm{~m}$ and occurs just below the very fine sand unit. On the other hand, the fine to medium sand unit shows minimum thickness and shallow depth (less than $62 \mathrm{~m}$ ) in the eastern part of the area.

The section BB' (Fig. 2b) shows the similar distribution of very fine sand unit as in the AA' (Fig. 2a). In this section very fine to fine Sand unit occupies the major proportion in the central part of the area that continues up to the explored depth $(300 \mathrm{~m})$ with a thickness of about $280 \mathrm{~m}$ at VES 8. Medium to coarse sand unit is almost absent along the section. In addition, the proportion of fine to medium sand and medium sand units 


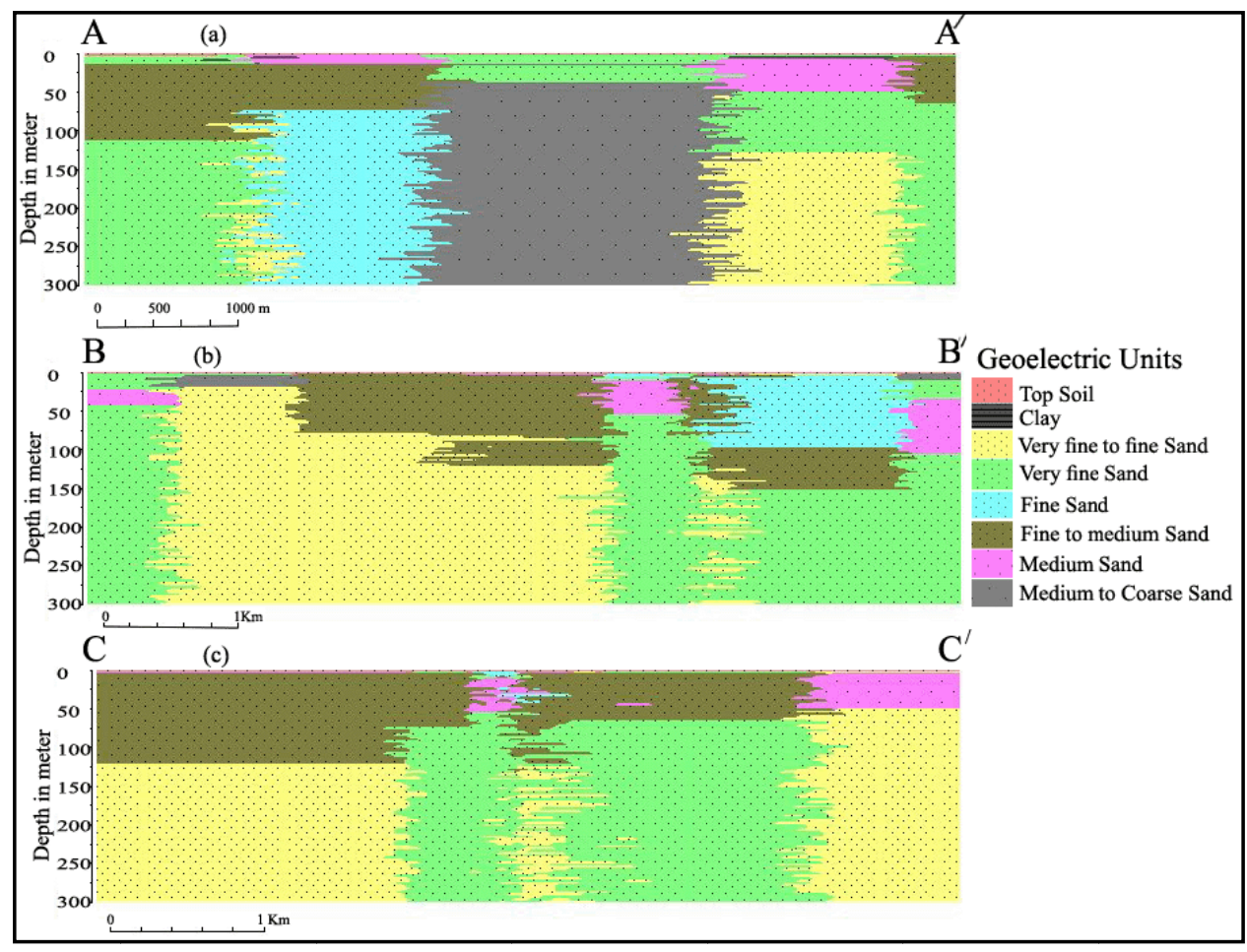

Fig. 2. Geoelectric cross-section along a) AA', b) BB' and c) CC'.

are higher in amount in section AA'. The cross section along CC' (Fig. 2c) in north south direction shows that the distribution of lithology in the area is slightly different from eastwest distribution. Fine to medium sand unit is the major unit in the upper $100 \mathrm{~m}$ of depth while the very fine to fine sand is the dominant lithology which occurs at both northern and southern part of the section and vertically continues up to 300 meter depth.

Sandy material capable of holding and transmitting groundwater serves as aquifer/ ground water reservoir and silty clay to clay materials capable only of holding groundwater is termed as aquitard.

In terms of hydrogeology, the subsurface of the study area is broadly divided into two units based on the analyzed VES results. The top surface unit composed of silty clay to clay or even in some places silty sand may play the role as aquitard.

It is very thin (1 to 5 meter) that floors the entire study area. Physical and hydraulic properties of the unit are very important as they regulate the vertical recharge to the underlying aquifers. The sandy unit on the other hand that integrated all sizes of sand materials (Fig. 3) acts as regional aquifer and is used for ground water development in the Pourashava area for water supply. 


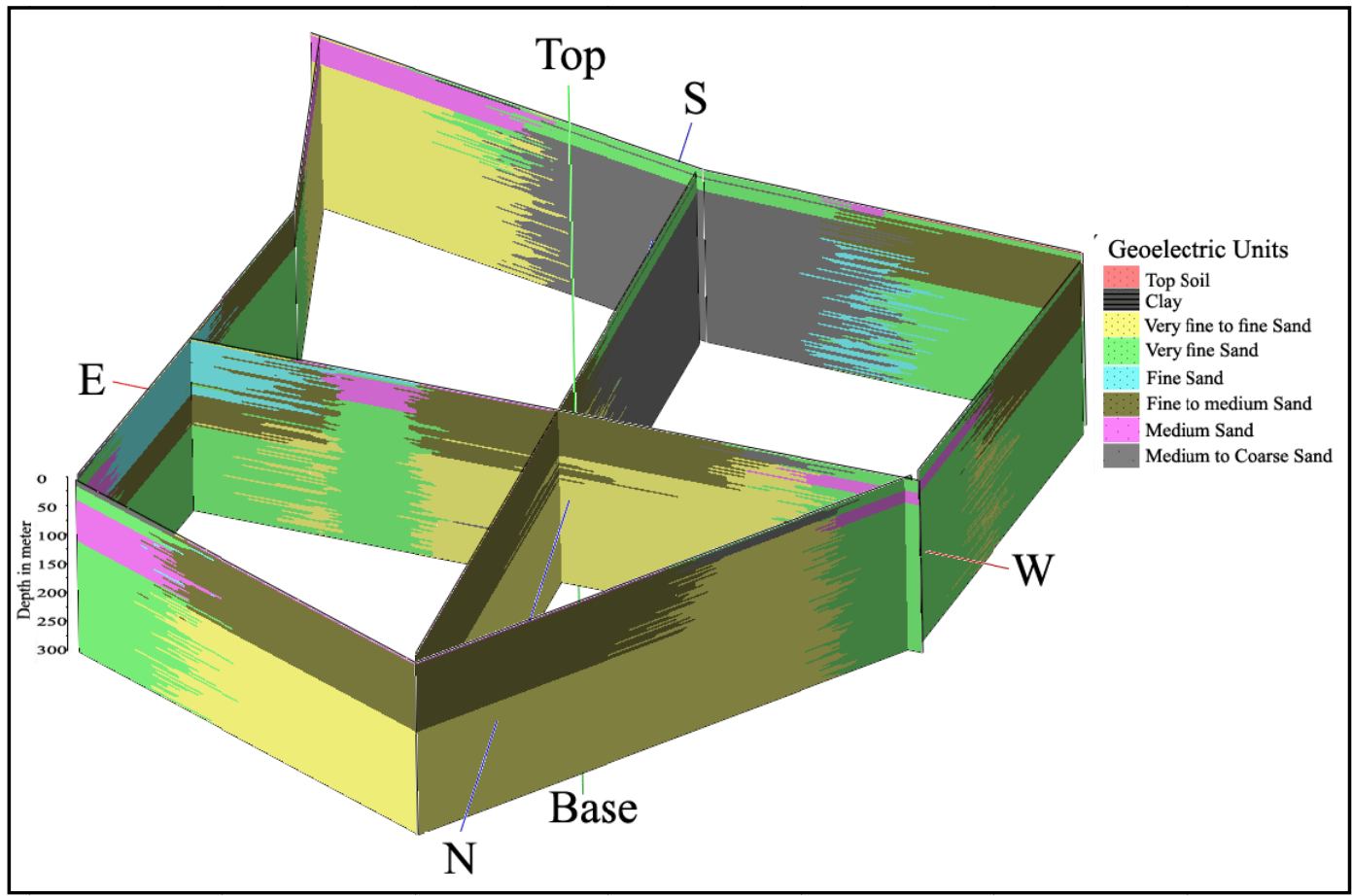

Fig. 3. Vertical distribution of lithology represented in a 3-D panel diagram.

The subsurface lithological distribution in the area demonstrates that the area varies in composition in lateral and vertical directions. But it has been deciphered that the aquifer in south central part of the area could be the source to abstract substantial groundwater to enhance the water supply to the Pourashava area because of medium to coarser material at that area with reasonable thickness.

\section{Conclusions}

In most parts of Bangladesh tubewells installed at shallow depths (15 - 50m) are found to be highly arsenic contaminated. The Pourashava area of Manikganj located in the central part of Bangladesh is treated as arsenic hotspot in the country as the outcome of various studies concludes that almost $80 \%$ of the domestic tube wells at this area exceeds arsenic level of Bangladesh standard (50 $\mu \mathrm{g} / \mathrm{l})$ for drinking water. To enhance the potable water supply in the area, 15 geoelectric soundings survey using Schlumberger configuration with spreading $\mathrm{AB} / 2=300$ meters has been executed to decipher the subsurface lithology distribution and aquifers at different depths, to determine the lateral and vertical extent of aquifer at the area. Correlation of the analyzed VES results with primary and secondary borelogs, the subsurface sequence of the area is broadly divided in to two geoelectric 
units. Firstly, the near surface geoelectric unit of resistivity less than $20.0 \Omega$-m represents the Top Soil composed of silty clay to clay. The thickness of this layer varies from 1 meter to 5 meters. The second geoelectric unit represents the sand layer and is characterized by a resistivity range of 21.0 to $190.0 \Omega-\mathrm{m}$. This unit encompasses the very fine Sand with variable thickness of 2 to $248 \mathrm{~m}$ while resistivity is from 21.0 to $30.0 \Omega$ $\mathrm{m}$, very fine to fine Sand having thickness from $174-280 \mathrm{~m}$ and resistivity value ranges from 31.0 to $40.0 \Omega-\mathrm{m}$, fine Sand- resistivity from 44.0 to $50.0 \Omega-\mathrm{m}$, fine to medium sand -resistivity from 51.0 to $70.0 \Omega-\mathrm{m}$, medium sand and medium to coarse sand -resistivity values 75.0 to $110.0 \Omega-\mathrm{m}$ and 140.0 to $190.0 \Omega-\mathrm{m}$, respectively. The ultimate thickness of this unit is not determined due to limited spread but at least continues to a depth of 300 $\mathrm{m}$. In terms of hydrogeology, the subsurface of the study area is broadly divided into two units based on the analyzed VES results. The top surace unit composed of silty clay to clay may act as aquitard. It is very thin ( 1 to 5 meter) that floors the entire study area. The sandy unit on the other hand, sand unit integrating of all sizes of particles acts as regional aquifer and is used for ground water development in the Pourashava area for water supply.

\section{References}

ATSDR (Agency for Toxic Substances and Disease Registry). 2007. Toxicological profile for arsenic., US Department of Health and Human Services, Atlanta, Georgia.

BGS and DPHE. 2001. Arsenic contamination of groundwater in Bangladesh, BGS. Technical Report, Volume 2: Final Report. British Geological Survey, Keyworth.

Bugg, S. F. and J.W. Lloyd. 1976. A study of fresh water lens configuration in the Cayman Island using resistivity method. Q. J. Eng. Geol. pp. 9291-9302.

BWBD. 2004. Groundwater level records of Manikganj station. Bangladesh Water Development Board, Dhaka Bangladesh.

Rahman, M.M., A. S. M. Woobaidullah, Kazi Matin Ahmed, M. Aziz Hasan, M Hossain, Prosun Bhattacharya, Mattias von Bromssen, Gunnar Jacks. 2013. Evaluation of Hydrogeological Conditions through Vertical Electrical Soundings Survey in regions with high arsenic groundwater at Matlab, Southeastern Bangladesh, Accepted, Journal of Earth and Environmental Sciences (JEES), Dhaka University. 2(2): 1-8.

Serres, Y. F., 1969. Resistivity prospecting in a United Nation groundwater project of western Argentina. Geophysical Prospecting. 17: 449-467.

UNDP. 1982. Groundwater Survey, the hydrogeological condition of Bangladesh. UNDP Technical Report. DP/UN/BGD-74-009/1.

Woobaidullah, A. S. M., and Mohammad Zohir Uddin. 2011. Geoelectric resistivity sounding for deciphering hydrogeology and locating deep tubewell installation sites in Pouroshava area of Bagerhat, Bangladesh. Jour. Nepal Geol. Soc. 42: 99-108. 
Woobaidullah, A.S.M., Shahid Hossain Chowdhury, K. Matin Ahmed, Mohammad Wahidur Rahman, Khandker Sadia Arafin and Obaidullah Al-Ejaz. 2008. Geo-electric Resistivity Survey in the Evaluation of Hydrogeological Condition in Haziganj Upazila, Chandpur District, Bangladesh. Jour. Geol. Soc. India 72(6): 753-763.

Woobaidullah, A. S. M., K. M. Ahmed, M. A. Hasan and M. K. Hasan. 1998. Saline ground water management in Manda Upazila of Naogaon District, NW Bangladesh. Jour. Geol. Soc. India, 51: 49-56.

Woobaidullah, A.S.M., M. Rahman and R. Arndt. 1996. Electrical survey for groundwater exploration in the coastal belt of Satkhira, north-west Bangladesh. Jour. Geologiche Bundes Anstalt, Austria. pp. 127-137.

(Manuscript received on 08 June, 2014; revised on 09 September, 2014) 
Bangladesh J. Sci. Res. 27(2): 121-131, 2014 (December)

\title{
CHEMICAL SUITABILITY OF GROUND WATER FOR IRRIGATION IN TRIMOHONI AND SAGARDARI UNION, KESHABPUR UPAZILA, JESSORE, BANGLADESH
}

\author{
S. K.Saha*, B. M. Rabby Hossain ${ }^{1}$, Md. Anwar Jahid ${ }^{2}$ \\ Department of Geology, University of Dhaka, Dhaka-1000, Bangladesh
}

\begin{abstract}
The paper intends to provide guidance to evaluate and identify a standard ground water chemistry data for irrigation in south western region of Bangladesh. During the course of hydrogeological studies in the study area, twenty water samples were collected from twenty different villages and chemically analyzed. The analytical results revealed that the water was slightly acidic to slightly alkaline ( $\mathrm{pH} 6.68$ - 7.32) and TDS values range from 565 to $1073 \mathrm{mg} / \mathrm{l}$. The other parameters like sodium adsorption ratio, (SAR) (0.10 0.27), sodium percentage (3.22 - 7.13), residual sodium carbonate, (RSC) (3.2 5.33) and potential soil salinity, (PS) (less than 30) were below the desired limit suggesting the suitability for irrigation purpose. Considering SAR, permeability index and salinity hazard, all waters could be applied safely for irrigation without any hazard to crops.
\end{abstract}

Key words: Ground water, irrigation, water chemistry, south-west Bangladesh

\section{Introduction}

Irrigation is an age-old art. Historically, civilization has followed the development of irrigation. The duration of civilized people is probably dependent on many factors, of which a permanent profitable agriculture is significantly important (Hansen et al. 1979). Around 80\% people in Bangladesh are living in rural areas (BBS 2001) and are belonging to agrarian structure. Food security of that inhabitant is mainly agro based. The agriculture sector plays a pivotal role in the economy of the country accounting for 31.6 per cent of total GDP in 2000-2001. The agricultural sector comprises of crops, forests, fisheries and livestock. Of the agricultural GDP, the crops sub-sector contributes to 71 per cent itself. Keshabpur Upazila (Fig. 1) belongs to mature deltaic plain (Choudhury 2001). More especially this area is a part of Gopalganj-Khulna peat basin. Differences in elevation between river banks and basin centre usually are about one meter (Brammer 1997). During the time that the delta was being built, the activity of the river Ganges helped to build it up latter as a plain (Abedin et al. 1990). Kopothaksha is the main river

\footnotetext{
* Corresponding author: <sahask03@gmail.com; sks@univdhaka.edu>. Department of Disaster Science and Management, University of Dhaka, Bangladesh. ${ }^{2}$ Institute of Water Resources and Flood Management, Bangladesh University of Engineering and Technology, Dhaka-1000.
} 